\title{
The Influence of Capital Structure on Organizational Performance at Taiwan-Listed Info- Electronics Companies: Using Corporate Governance as the Moderator
}

\author{
Chai-Hui Chao* \\ Hsing Wu Institute of Technology, New Taipei City, Taiwan
}

\begin{abstract}
The purpose of this study is to verify the influence of capital structure on organizational performance at Taiwan-listed info-electronics companies, with corporate governance being the Moderator. Financial section chiefs or employees of higher levels at Taiwan-listed info-electronics companies were interviewed, while convenience sampling was used to yield knowledge from the population, the linear Structural Equation Modeling (SEM) was adopted to verify the goodness-of-fit effects among the overall model, structural model and measurement model. Findings from this study show that, at Taiwan-listed info-electronics companies, the capital structure and corporate governance both have significant interactive influence on the organizational performance. This implies Taiwan-listed-electronics companies should emphasize corporate governance just as also enhancement in capital structure.
\end{abstract}

Keywords: capital, organizational performance, corporate governance, electronic companies, financial crises

\section{Introduction}

A series of financial crises has occurred in recent years at Taiwan-listed info-electronics companies, quite a few of which were large, well-established enterprises such as the Procomp Informatics Ltd., Royal information Electronics Co. and Info disc Technology Co. One of the reasons why there were so many local companies hit by financial crises might be the lack of a sound corporate governance mechanism in Taiwan's regulations (Cheng, 2008). As a matter of fact, an "external corporate directors/supervisors" system has already been introduced at the Economic Development Advisory Conference (EDAC) back in July 2001. When the Securities and Futures Commission under the Ministry of Finance issued an executive order in February 2002 saying that "all recently listed companies, including OTC-listed ones, shall hire two external directors and one external supervisor", the presence of external directors had become one of the criteria for approving recently listed companies' entrance into the market, although it has no binding power at all on companies that were already publicly traded. Despite that non-binding executive order, Morris Chang, the founding father of Taiwan Semiconductor Manufacturing Company (TSMC), said it is imperative that a sustainable developmentminded company eagerly advocate corporate governance and the external director system. To set an example for the other local firms, TSMC became the first company in Taiwan to hire three internationally

\footnotetext{
*Email: 083016@mail.hwc.edu.tw
}

well-known experts as external directors and supervisors, namely Lester Thurow, professor of economics of MIT's Sloan School of Management; Michael Porter, a Bishop William Lawrence University Professor at Harvard Business School; and Sir Peter Bonfield, former CEO of British Petroleum PLC. The TSMC move sparked the popularity of corporate governance as well as the external director system among Taiwanese firms.

A sound governance mechanism helps a company avoid and lower agency cost while improving organizational performance by building a mechanism that ensures it is managed and monitored in its best interests (Chuang, 2004). But some studies hold an opposing view that company managers are likely to take measures unfavorable to shareholders when the ownership is increasingly concentrated in their hands as they seek to strength the authority and private interest, hence the deteriorated organizational performance. Therefore whether a sound corporate governance system will affect a company's organizational performance, or EV, is truly a critical issue (Jensen \& Ruback, 1983).

Meanwhile, a company with a demand for funding may raise funds either by issuing new shares or by obtaining loans. While the issuance of new shares results in a larger group of external shareholders that further complicates the agency problem between managers and shareholders, fundraising by means of loans increases the company's credit risks and subsequently the agency cost of shareholders and creditors alike. Therefore it is imperative that equilibrium be found among various costs in order to 
determine a company's capital structure. Given the ever-growing number of available financial tools, the financial policy is offering a widened variety of methods to make loan decisions. As for loan-relevant decisions, the cost of capital, financial risks, obligations imposed by creditors, length of fund-supplying period, and potential agency problem must all be taken into consideration when addressing issues pertaining to fundraising. Meantime, the company shall make loan decisions while using financial leverage to determine the consequent cost of capital, so as to exert an influence on the organizational performance/ Enterprise Value (EV) (Jensen \& Meckling, 1976; Cheng, 2008).

Taiwan-listed info-electronics companies as the focus of attention in the country' high-tech sector proved successful mostly because they boast the world's most comprehensive vertical integration model of upper-, middle- and lower-stream firms, which led to the Taiwanese "economic miracle" with much economic significance. Also, such companies have won substantial recognition from investors worldwide for their extraordinary performances. Compared to their counterparts in traditional industries, the info-electronics firms are characterized by a short product life-cycle as well as a focus on technology- and capital-intensiveness.

The relatively short product life-cycle prompts such firms to continuously develop products and adopt new technologies for the manufacturing process, which will eventually lift the organizational performance and EV. Consequently, this study was intended to scrutinize Taiwan's info-electronics companies, to build a research model based on previous literature and verify its goodness-of-fit effects. The specific purposes of this study are listed as follows:

1) To verify and understand whether capital structure has a positive and significant influence on the organizational performance at Taiwan's info-electronics companies; 2) To verify and understand whether internal corporate governance has a positive and significant influence on the organizational performance at Taiwan's info-electronics companies. 3) To verify and understand whether the capital structure and corporate governance have significant interactive influence on the organizational performance of Taiwan's info-electronics companies; 4) To generate findings that provides references for decision makers at Taiwan's infoelectronics companies when implementing corporate governance.

\section{Literature Review}

Not only does this section explore how findings from previous studies are linked to the topic of this present study, it also infers hypotheses from a literature review while establishing a research framework. The relevant theories and studies are stated as follows:

\section{Capital structure}

Yang (1993) noted that a company's capital structure is significantly affected by how capital-intensive, profitable and large it is, and also by the percentage of shares held by directors/supervisors. Capital structure is the sources of capital planned for long-term debts and shareholders' equity that appear on the right side of a balance sheet; it mostly helps determine the optimal combination of sources of funding (Lai, 1993). The Debt-to-Equity Ratio (D/E), current ratio, and the ratio of short-term debts to total debts are adopted as variables in most of the previous studies addressing corporate capital structure or financial policies (Liu, 2002; Lu, 2005; Cheng, 2008). Lu (2005) said D/E implies two distinctively different effects (i.e., the tax shelter effect and cost of expected financial crises) as part of the financial leverage's influence on corporate operating performance. Lu therefore argued that, by analyzing the $\mathrm{D} / \mathrm{E}$ in a regression equation, we may see how it affects the EV. Meanwhile, Cheng (2008) noted that using short- and long-term $\mathrm{D} / \mathrm{E}$ as variables in a study will lead to a high multi-co linearity.

According to Cheng (2008), the capital structure is all about a company's long-term loans. To build long-term current assets, a company almost always obtains loans through long-term debts. By securing a long-term source of funding in the capital market, a company changes its capital structure in an attempt to enhance the overall ratings received, and eventually improve its price per share and EV. To summarize the afore-mentioned academic views, this present study decided to give capital structure the conceptual definition of "long-term debts plus the sources of funding for shareholders' equity", with the two capital structure variables being "the ratio of long-term debts to overall debts" and "D/E".

\section{Corporate governance}

Li (2006) used corporate governance variables that include the size of board of directors, the percentage of shares held by directors/supervisors, the ratio of shares pledged by directors/supervisors, the CPA attestation report, replacement of CPA, and whether or not the chairman also serves as the company's president.

Cheng (2008) defined corporate governance as "the rights and obligations of all participants in a company, including the managers, shareholders, board of directors, or any other party with interests involving the company, along with a set of rules/procedures laid down for a company's management-related matters". Cheng (2008) explored the issue of corporate governance using such variables as the percentage of shares held by managers, the percentage of shares held by major shareholders, the size of the board of directors, and the 
percentage of shares held by external directors. Based on the proposal of Cheng (2008), this present study gave corporate governance the conceptual definition of "the rights and obligations of a company's management, shareholders, board of directors, or any other party with interests involving the company, along with a set of rules/procedures laid down to manage the company's operations". In this study, corporate governance contains variables including the size of board of directors, the percentage of shares held by external directors, the percentage of shares held by directors/supervisors, the ratio of shares pledged by directors/supervisors, the percentage of shares held by managers, the CPA attestation report, and whether the chairman also serves as the company's president.

\section{Organizational performance}

Originally indicating how well the results of an effort are shown, the phrase "performance" is a concept of two tiers, namely efficiency and effectiveness. While efficiency is the ratio between output and input, effectiveness is the degree of goal achievement for an organization. Organizational operations are pursuits of successful outcomes that combine efficiency with effectiveness. According to the motivation theory in management science, it is interpreted as "a price of work completed by an employee" (Wang, 1997). The science of organizational behavior, nevertheless, refers to performance as "an integrated success consisting of efficiency, effectiveness and efficacy" (Xie, 2006).

According to $\mathrm{Xu}$ (2007), operating performance is the degree of a company achieving its strategic goals, as well as an indicator for the examination of the company's overall competitiveness. When conducted properly, the evaluation of organizational performance will give an organization's manager an idea of the current conditions of his/her organization. The evaluation indicators used the most often are an organization's income, production capacity and profitability. $\mathrm{Xu}$ argued that efficiency and effectiveness should be integrated into the concept of organizational performance. Drucker (1966) gave a good interpretation of efficiency and effectiveness by saying that former is "doing things in the right way", and the latter "doing the right things". Neither efficiency nor effectiveness should be neglected, although that doesn't mean they have equal significance. We surely wish to enhance efficiency and effectiveness simultaneously. But if that is unlikely, we must prioritize effectiveness and manage to boost efficiency later. There is a massive amount of previous studies addressing the measurement dimensions of organizational performance. Since the benefits of organizational performance will eventually be fed back to the financial dimension, most scholars in this field adopt financial performance as one of the measurement indicators. In an environment characterized by convenient ways of information delivery and rapidchanging markets, nevertheless, a company nowadays shall never solely rely on financial performance to achieve survival and competitiveness. That is to say, it is impossible to sufficiently gauge the organizational performance using financial performance as the sole indicator (Ling \& Hong, 2010).Moreover, Ling and Hong (2010) argued that organizational performance is the sum of accomplishments attained by all businesses/departments involved with an organizational goal during a determined period of time, with the goal either meant for a specific stage or on the overall extent.

This present study is patterned after the research projects conducted by Daft (1978), Delaney and Huselid (1996), Johns and Johnes (1993), Wu (1998) and Ling and Hong (2010). In order to measure both the financial and non-financial aspects of organizational performance and to correctly gauge the influence of job satisfaction and internal-service quality on organizational performance, this paper defines financial performance as the output in terms of financial accounting that can be measured by indices regarding growth and profitability. For example, a company with satisfying financial performance is expected to exceed the average in the same sector regarding the Earnings per Share (EPS) and Return on Sales (ROS) as well. The non-financial aspect of organizational performance, on the other hand, is measured by means of innovation-related performance, which in turn is gauged from the multiple perspectives of organizational innovation that involves both technological and managerial innovations. The technological innovation here refers to technologies required by an organization for manufacturing products or providing services, while a managerial innovation occurs in the organization's social system and is related to the hiring/management processes and the organizational structure (Daft, 1978; Damanpour \& Evan, 1984; Johns, 1993; Kimberly \& Evanisko, 1981; Ling \& Hong, 2010). The "influence of capital structure on organizational performance" discussed in this present study mostly involves two components of organizational performance: innovation performance and EPS (Chang \& Lee, 2012).

\section{The influence of corporate governance on organizational performance}

Both Alchian and Demsetz (1972) believe that an excessively high degree of diffuse ownership loosens the company's control over its managers, which will in turn affect the EV. A major shareholder, according to Taiwan's Securities Exchange Act, is someone who actually holds $10 \%$ or more of a company's common 
shares. With shares divided into a larger number of small holdings, the diffuse ownership will bolster the demand for shareholder monitoring and also the disclosure of additional information.

According to Zahra and Pearce (1989), the larger the board of directors, the better it functions as the company's monitor and advisor. A board of directors consists of internal directors and external directors, the former being those doubling as non-directors and the latter being directors holding no position whatsoever in the company. Compared to the internal directors, the external ones usually display more professionalism and independence. That is why they execute monitoring tasks more easily, making it less possible for high-level managers to connive with one another and/or to use company assets abusively.

Yermack (1996) conducted a study that said a comparatively small-sized board of directors tend to lack effectiveness compared to a larger one, hence the positive correlation between the size of board of directors and Tobin's Q. A larger portion of shares held by external directors, or a larger percentage of external directors sitting on the board, is linked to a larger EV. In other words, external directors' functioning as independent supervisors/evaluators ensures increased efficiency in corporate decision making. Hong (2006) argued that shares held by institutional investors and extraordinary corporate governance both exert a significant and positive influence on the performance of a company, whether it is incorporated or unincorporated. Among others, the shares held by foreign investors are particularly influential. Wang (2006) conducted a study that said the structure of ownership and that of the board of directors both have crucial influence on EV. Companies with a good corporate governance system tend to attract a larger number of investors since it ensures all investors a reasonable return on their money. That explains why corporate governance influences the performance in a positive, significant manner (Cheng, 2008). The following hypotheses can be drive from the aforementioned inferences:

Hypothesis 1 (H1): Corporate governance has a positive and significant influence on organizational performance at Taiwan-listed info-electronics companies.

\section{The influence of capital structure on organizational performance}

Based on theories regarding the relevance of capital structure, Modigliani and Miller (1963) noted that the company/personal income tax functions as a tax shield for a company. The large amount of loans, the greater benefits (thanks to the tax shelter effect) and larger EV a company enjoys. Therefore obtaining loans helps bolster the EV, and debts are positively correlated to EV. Li (1998) said an increase in D/E sends profits tumbling. Citing conclusions from an empirical study, he argued that there is a significantly negative correlation between D/E and EPS because infoelectronics firms facing high risks tend to rely on own funds to cope with their massive demand for upcoming investment funding. Such an attempt to meet the demand for funding with a larger percentage of own funds, nevertheless, could reduce both the overall D/E and hefty interest payments, and eventually bolster the operating performance with increased after-sales profits. In her empirical study Cai (2000) found that, at companies with a relatively larger or smaller Equity Growth Rate, the D/E invariably has a positive yet insignificant influence on EV and the operating performance. When a company's operating performance or Tobin's Q is larger than 1, according to Hou (2004), the insufficient investment and agency problem will become relatively less significant. That is, companies seeking loans are able to achieve a positive growth. On the foundation of inferences mentioned above, this present study developed the following hypotheses awaiting verification:

Hypothesis 2 (H2): Capital structure has a positive and significant influence on organizational performance at Taiwan-listed info-electronics companies. And yet, whether or not capital structure and corporate governance exert a synergetic effect on the organizational performance is an issue worth discussing, hence the third derived hypothesis:

Hypothesis 3 (H3): Capital structure and corporate governance exert a significant interactive influence on the organizational performance of Taiwan-listed infoelectronics companies.

\section{Research Method}

The purpose of this study was to verify the influence of capital structure on organizational performance at Taiwan-listed info-electronics companies, with corporate governance being the Moderator. The questionnaire for this study was designed on the basis of multi-dimension measurement. It uses a 7-point Likert scale to measure each answer, with 7 being strongly agree and 1 being strongly disagree. A higher point represents a higher degree of agreement, and vice versa. And then data collected from the samples was "centralized", so the sum of scores given to all questionnaire items after deducting the average is zero. That way, the multicollinearity between independent and extraneous variables will be erased to better test the interactive influence of independent variables on the extraneous variable. The following mathematical equation illustrates the "centralization" concept: $\Sigma(\mathrm{Xi}$ $-)=\Sigma \mathrm{Yi}=0$. 
The questionnaires for the dimension of "capital structure" were patterned by Ai-Zhi Lu (2005) and LinJu Cheng (2008). The questionnaire of "corporate governance" was designed on the foundation of the ones proposed by Fu-Li Li (2006) and Lin-Ju Cheng (2008). The measurement indicators of "organizational performance" include innovation performance and EPS, the former being patterned after the one proposed by Ya-Hui Ling and Ling Hong (2010) and the latter the Taiwan Economic Journal (TEJ) Database. This study conducted a questionnaire-based survey on the financial section chiefs or financial staff of higher levels at Taiwan-listed info-electronics companies, selected using convenience sampling. 15 copies of expert questionnaire were administered in a pilot-test. A post-test was conducted after modifying the questionnaire in accordance with expert suggestions. 250 copies of the official questionnaire were distributed, with 221 valid copies returned at a return rate of $88.4 \%$. To verify the research framework proposed, a linear SEM was applied to the Confirmatory Factor Analysis (CFA) of the research model's framework. The questionnaire was divided into three latent variables (i.e., capital structure, corporate governance and organizational performance), each containing several observable/explicit variables. The survey was conducted using these observable/explicit variables, with several questionnaire items categorized under them each. After processing data collected in the survey, files were created for the primary data. Although the questionnaire design was based on Multi-Dimension Measurement, either "Dual Measurement" or "Single Measurement" was adopted to make sure the computer software-aided data processing goes as expected (Shun-Yu Chen, 2010). Table 1 shows the number of questionnaire items under implicit and explicit variables in this study (Chang \& Lee, 2012).

Table 1. The number of questionnaire items for implicit variables and observable variables.

\begin{tabular}{clc}
\hline Implicit variables & Explicit variables & Number of questions \\
\hline Capital structure & Ratio of long-term debts to total debts & 4 \\
$(\mathrm{X})$ & D/E & 4 \\
\hline Corporate & Size of board of directors; percentage of shares held by & \\
governance (Mo) & external directors & 4 \\
& Percentage of shares held by directors/supervisors & 4 \\
& Percentage of shares pledged by directors/supervisors & 4 \\
& Percentage of shares held by managers & 4 \\
& CPA attestation report & 4 \\
& Chairman and president & 4 \\
\hline Organizational & Innovation performance & 4 \\
performance (Y) & EPS & 4 \\
\hline
\end{tabular}

\section{Results and Analysis}

\section{Linear structure model analysis}

The CFA is an analytical approach opposite to the Exploratory Factor Analysis (EFA). This study conducted a CFA of three unobservable/implicit variables (i.e., capital structure, corporate governance and organizational performance). Consisting of the Structural Model and Measurement Model, a SEM provides an effective solution to the cause-effect relation between implicit/latent variables. The models verified in this study are divided into three parts: (1) verifying the goodness-offit of Measurement Model; (2) verifying the goodnessof-fit of Structural Model; (3) verifying the overall model's goodness-of-fit to make sure it conforms to the goodness-of-fit indices. That is, the goodness-of-fit of the overall SEM was judged with related goodness-of-fit indices (Diamantopoulos \& Siguaw, 2000; Chang \& Lee, 2012).

\section{Analyzing fit of measurement model}

The factor loading of latent/implicit variables and manifest/ explicit variables mainly measures the intensity of linear correlation between explicit and implicit variables. A factor loading close to 1 indicates the explicit variable is relatively capable of measuring the implicit one. In this study, all explicit variables' factor loading are between 0.7 and 0.9 , hence the satisfying reliability. Consequently, all explicit/manifest variables in the model's measurement system are capable of appropriately measuring the implicit/latent variables. Moreover, the Average Variance Extracted (AVE) is used to calculate the explanatory power of variance between implicit/latent variables versus explicit/manifest ones; the higher the VE value, the greater reliability and convergent validity of the latent/implicit variables. Usually, the VE value must be larger than 0.5 to indicate the explanatory variance of explicit variables is larger than measurement error (Fornell \& Larcker, 1981; Chang \& Lee, 2012). In this study, all AVEs are larger than 0.5, hence the explicit variables' excellent reliability and convergent validity (See Table 2 and Figure 2). 
Table2. Judgment indicators of measurement system in the model.

\begin{tabular}{lccc}
\hline Unobservable/implicit variables & $\begin{array}{c}\text { Observable variables: Centralized dual } \\
\text { measurement }\end{array}$ & $\begin{array}{c}\text { Factor loading } \\
\text { Variance extracted } \\
\text { (VE) }\end{array}$ & $\begin{array}{c}\text { X } \\
\text { Capital Structure (X) }\end{array}$ \\
& X1C & 0.82 & 0.63 \\
Corporate Governance (MO) & Z1C & 0.83 & 0.61 \\
& Z2C & 0.83 & 0.62 \\
X*MO & X1Z1C & 0.85 & 0.61 \\
& X2Z2C & 0.84 & 0.66 \\
Organizational Performance (Y) & M1C & 0.86 & 0.67 \\
& M2C & 0.82 & 0.56 \\
\hline
\end{tabular}

\section{Analyzing fit of structure model}

Path analysis results of structure model

After the overall model passed the goodness-of-fit test, Table 3 shows such results as the parameter estimates,
S.E. and Critical Ratio (C.R.) between implicit variables. Capital structure and investments in Corporate governance $(\mathrm{X} * \mathrm{MO})$ both have a significant interactive influence on Organizational Effectiveness (Y) because $\mathrm{c}=0.684$.

Table3. Path analysis results of the structural model.

\begin{tabular}{|c|c|c|c|c|c|c|c|}
\hline \multicolumn{3}{|c|}{ Path coefficients between implicit variables } & \multirow{2}{*}{$\frac{\text { Estimate }}{.381}$} & \multirow{2}{*}{$\frac{\text { S.E. }}{.083}$} & \multirow{2}{*}{$\frac{\text { C.R. }}{4.590}$} & \multirow{2}{*}{$\frac{\mathrm{P}}{* * *}$} & \multirow{2}{*}{$\frac{\text { Label }}{a}$} \\
\hline Capital Structure (X) & $\rightarrow$ & $\begin{array}{l}\text { Organizational } \\
\text { Performance }(\mathrm{Y})\end{array}$ & & & & & \\
\hline $\begin{array}{l}\text { Corporate Governance } \\
\text { (MO) }\end{array}$ & $\rightarrow$ & $\begin{array}{l}\text { Organizational } \\
\text { Performance (Y) }\end{array}$ & .392 & .031 & 12.645 & $* * *$ & $\mathrm{~b}$ \\
\hline $\mathrm{X}^{*} \mathrm{MO}$ & $\rightarrow$ & $\begin{array}{l}\text { Organizational } \\
\text { Performance (Y) }\end{array}$ & .684 & .023 & 29.739 & $* * *$ & $\mathrm{c}$ \\
\hline $\mathrm{X}$ & $\rightarrow$ & $\mathrm{X} 1 \mathrm{C}$ & .862 & .162 & 5.321 & $* * *$ & \\
\hline $\mathrm{X}$ & $\rightarrow$ & $\mathrm{X} 2 \mathrm{C}$ & .873 & .162 & 5.389 & $* * *$ & \\
\hline $\mathrm{MO}$ & $\rightarrow$ & $\mathrm{Z1C}$ & .841 & .333 & 2.526 & $* * *$ & \\
\hline MO & $\rightarrow$ & $\mathrm{Z} 2 \mathrm{C}$ & .823 & .323 & 2.548 & $* * *$ & \\
\hline $\mathrm{X}^{*} \mathrm{MO}$ & $\rightarrow$ & $\mathrm{X} 1 \mathrm{Z1C}$ & .742 & .284 & 2.613 & $* * *$ & \\
\hline $\mathrm{X} * \mathrm{MO}$ & $\rightarrow$ & $\mathrm{X} 2 \mathrm{Z} 2 \mathrm{C}$ & .793 & .281 & 2.822 & $* * *$ & \\
\hline Y & $\rightarrow$ & M1C & .833 & .142 & 5.866 & $* * *$ & \\
\hline Y & $\rightarrow$ & M2C & .843 & .143 & 5.895 & $* * *$ & \\
\hline
\end{tabular}

Note: * indicates $\mathrm{P}<0.05$; ** indicates $\mathrm{P}<0.01$; *** indicates $\mathrm{P}<0.001$

\section{Coefficient of determination}

Also known as Squared Multiple Correlation (SMC), the Coefficient of Determination is the degree of explanatory power of "independent variable" regarding "dependent variable" under each implicit variable. In other words, the R2 value shown in Table 4 indicates that the implicit independent variable has adequate explanatory ability on the implicit dependent variable respectively.

Table 4. Coefficients ${ }^{\mathrm{a}}$ [Hierarchical regression].

\begin{tabular}{|c|c|c|c|c|c|c|c|c|c|}
\hline \multirow[t]{2}{*}{ Model } & \multirow[t]{2}{*}{$\mathrm{R}$} & \multirow{2}{*}{$\begin{array}{c}\mathrm{R} \\
\text { Square }\end{array}$} & \multirow{2}{*}{$\begin{array}{l}\text { Adjusted R } \\
\text { Square }\end{array}$} & \multirow{2}{*}{$\begin{array}{l}\text { Std. Error of } \\
\text { the Estimate }\end{array}$} & \multicolumn{5}{|c|}{ Change Statistics } \\
\hline & & & & & R Square Change & F Change & df1 & $\mathrm{df} 2$ & Sig. F Change \\
\hline 1 & $.887^{\mathrm{a}}$ & .789 & .773 & .317 & .787 & 179.218 & 2 & 97 & 0.000 \\
\hline 2 & $.895^{\mathrm{b}}$ & .813 & .785 & .512 & .015 & 7.024 & 1 & 96 & 0.009 \\
\hline
\end{tabular}

Table 5 Coefficients ${ }^{\mathrm{a}}$

\begin{tabular}{cc}
\hline Coefficients of determination & $\mathrm{R}^{2}$ \\
\hline Capital Structure (X) and Corporate Governance (Mo) versus Organizational Performance & 0.789 \\
(Y) & \\
Capital Structure (X), Corporate Governance (Mo) and X*Mo versus Organizational \\
Performance (Y)
\end{tabular}




\section{Indices of fit of the overall model}

The purpose of adopting SEM in the modeling phase of this study is to explore the relationship between unobservable variables within the Structural Model, to examine whether the Measurement Model has measurement reliability or not, and also to measure the overall goodness-of-fit effects of this study using such indices as $\chi 2$, d.f., GFI, AGFI, NFI, CFI, RMR and
RMSEA. In most cases, it is required that $\chi 2 /$ d.f. $<5$, $1>\mathrm{GFI}>0.9,1>\mathrm{NFI}>0.9,1>\mathrm{CFI}>0.9, \mathrm{RMR}<0.05$ and RMSEA $<0.05$ (Bagozzi \& Yi, 1988). The goodnessof-fit of the overall model in this study is satisfying, given the fact that $\chi 2 /$ d.f. $<5$ and GFI, AGFI and NFI are all larger than 0.90, with the RMR value smaller than 0.05 , as shown as in Table 6 (Lee, Chao \& Chen, 2011; Chang \& Lee, 2012).

Table 6. Assessment of fit of the overall model.

\begin{tabular}{ccccccccc}
\hline Determination index & $\dot{\div}^{2}$ & DF & GFI & NFI & AGFI & CFI & RMR & RMSEA \\
\hline Fit value & 12.705 & 14 & 0.916 & 0.914 & 0.913 & 0.925 & 0.021 & 0.033 \\
\hline
\end{tabular}

\section{Standardized results of SEM analysis}

Figure.2 indicates the result of computer-aided standardization of the model's overall framework; besides, it can understand the coefficient of Capital
Structure (X) and Corporate Governance (Mo) is zero which shows that both variables are mutually independent. The former (Capital Structure) is independent variable, and the latter (Corporate Governance) is a moderator.

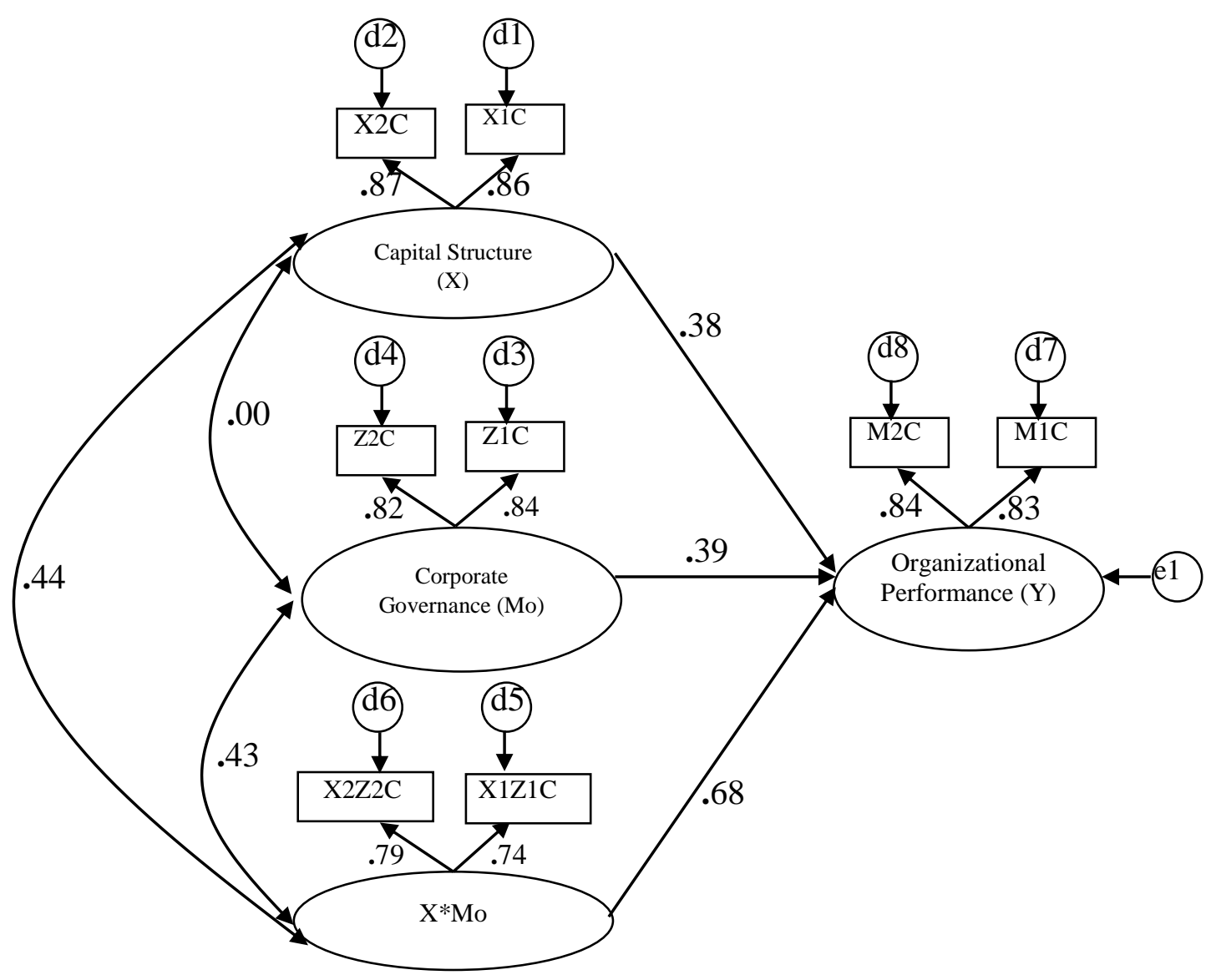

Figure 2. Standardized results of SEM analysis. Adapted from; Lee et al. (2012) and Chang \& Lee (2012). 


\section{Analytical testing of path effect for the structural model}

For the test of extraneous variable, this study performed a hierarchical regression analysis (see Table 5, followed by centralized hierarchical regression analyses and t-tests of $\mathrm{Y}$ versus $\mathrm{X}, \mathrm{Mo}$ and $\mathrm{X}^{*}$ Mo. These analyses were intended to test whether the significance of regression coefficient $\mathrm{c}$ is substantiated (i.e. whether c is zero or not). The test results are shown in Table 5.

Table 5. Coefficientsa.

\begin{tabular}{ccccrc}
\hline \multirow{2}{*}{ Model } & \multicolumn{2}{c}{ Unstandardized coefficients } & Standardized coefficients & $\mathrm{t}$ & \multirow{2}{*}{ Sig. } \\
\cline { 2 - 4 } & $\mathrm{B}$ & Std. Error & Beta & & \\
\hline 1 (Constant) & 3.817 & 4.181 & .455 & 4.911 & .000 \\
X & 9.754 & .902 & .181 & 10.935 & .000 \\
Mo & 6.885 & .422 & .363 & 13.344 & .000 \\
2 (Constant) & 5.036 & 5.561 & .451 & 4.913 & .000 \\
X & 9.197 & .625 & .381 & 10.936 & .000 \\
Mo & 6.373 & .116 & .392 & 13.354 & .000 \\
X*Mo & 15.407 & .531 & .684 & 27.965 & .000 \\
\hline
\end{tabular}

a. Dependent variable: Organizational effectiveness (Y).

The results from Table 5 showed that the Path Coefficient of $\mathrm{MO}^{*} \mathrm{X}$ versus $\mathrm{Y}$ is 0.684 , indicating the extraneous effect of $\mathrm{Mo}^{*} \mathrm{X}$ on $\mathrm{Y}$.

The above-mentioned analysis generated the following verified results: (i) Capital structure exerts a positive and significant effect on organizational performance with a 0.38 standardized path coefficient that supports H1 (Hypothesis substantiated); (ii) Corporate governance exerts a positive and significant effect on organizational performance with a 0.39 standardized path coefficient that supports $\mathrm{H} 2$ (Hypothesis substantiated); (iii) It is verified and understood that capital structure and corporate governance both have a positive and significant interactive influence on the organizational performance of Taiwan-listed info-electronics firms, with a 0.68 standardized path coefficient that supports H3 (Hypothesis substantiated).

\section{Conclusion and Suggestions}

The following specific conclusions are derived from the afore-mentioned data analyses and results:

The SEM established in this study has a satisfying goodness-of-fit in terms of the Measurement Model, Structural Model and the overall structure, hence a good model fitting.

The sound capital structure and satisfying corporate governance at Taiwan-listed infoelectronics companies both exert a significant interactive influence on the organizational performance. In other words, the "corporate governance" variable in this study has a positive extraneous effect. According to Shun-Yu Chen (2010), when both the extraneous and independent variables exert a significant interactive influence on the dependent variable, nether the independent nor the extraneous variable will affect a dependent variable significantly.

While the previous studies of info-electronics firms tend to focus on EFA, this present study performed modeling on the summarized results of previous literature in related fields. It also verified the model's goodness-of-fit to find out if this model has satisfying fit-of-goodness effects.

Consequently, this study is a CFA-based one that addresses a crucial topic regarding business practices. Not only is that topic worth further research in relevant fields, the research results also provide a reference for decision makers at Taiwan-listed infoelectronics companies in terms of corporate governance. That explains why this present study serves as an extremely valuable reference.

The previous literature pertaining to Taiwanese info-electronics companies almost always conducted exploratory research using the multi-regression analysis and rarely used the CFA-based research framework that takes into consideration the implicit variables' extraneous effect. But since the chief dimensions of this present study are implicit variables, CFA and linear SEM appear suitable as the measurement tool and model framework respectively. That explains why this study is relatively innovative in terms of methodology.

\section{Limitations}

This study adopted the non-probability, convenience sampling method for convenience purposes, with samples selected only on the "proximity" and "easy- 
to-measure" bases. That however resulted in a substantial sampling bias and a reduced reliability. Therefore future studies are advised to use simple random sampling or stratified random sampling instead;

This CFA-based study should ensure the verification model is as simple as possible and avoid complicated ones with a poor goodness-of-fit (ShunYu Chen, 2010). That is why this study focuses solely on how capital structure affects the organizational performance, with corporate governance being the extraneous variable. This study focuses solely on the CFA of Taiwan-listed infoelectronics companies.

As this study focuses solely on the CFA of Taiwan-listed info-electronics companies, future studies may consider either extending the scope of research or verifying the goodness-of-fit of companies in various other industries, so as to find out if the goodness-of-fit varies among industries in the same model (Chang \& Lee, 2012).

\section{References}

Alchian, A. A. \& Demsetz, H. (1972). Production, information costs, and economic organization, American Economic Review. 62(5), 777-795.

Cai, Pei-Zhen (2000). A study of corporate growth, capital structure and corporate performance: Taking the example of Taiwan-listed companies. MA, Department of Economics, National Tsing Hua University.

Chang, Chung-Ming \& Lee, Yu-Je (2012).Verification of the Influence of Intellectual Capital upon Organizational Performance of Taiwan-Listed Info-Electronics Companies with Capital Structure as the Mediator. The Journal of International Management Studies, 7(1), .80-91.

Chen, Shun-Yu (2010). SEM, Taipei: Psychological Publishing Co., Ltd.

Cheng, Lin-Ju (2008). A study of the correlations among corporate governance, capital structure and enterprise value, Business Review, Chinese Culture University, 13(1), 65-92.

Chuang, Tsung-Hsien (2004). An empirical study between the corporate governance mechanisms and firm performance, unpublished Master's thesis, Department of Accounting, Ming Chuan University.

Daft, R. L. (1978). Enpocket mobile media monitor US reveals young adults value mobile more than traditional media, by Enpocket Retrieved from: http://enpocket.com/wrapper/page/news/2005/july21.html.

Damanpour, F. \& Evan, W. M. (1984). Organizational innovation and performance: The problem of organizational lag, Administrative Science Quarterly, 29, 392-409.

Delaney, J. \& Huselid, M. (1996). The impact of human resource management practices. Academy of Management Journal, 39(4),949-969.

Diamantopoulos, A \& Siguaw, J. A. (2000). Introducing LISREL: A guide for the uninitiated, Thousand Oaks, CA: Sage.

Fornell, C. \& Larcker, D. (1981). Structural equation models with unobservable variables and measurement error, Journal of Marketing Research, 18(1), 39-50.

Hong, Pei-Jun (2006). A study of the correlations among institutional investor-held shares, corporate governance and corporate performance: Taking the examples of Taiwan- based Incorporate and Unincorporated Companies, unpublished Master's thesis, Graduate Institute of Finance, Kainan University.

Hou, Guang-Zhi (2004). A study of the correlations among corporate growth, Leverage and Tobit"Q at Publicly Traded Companies in Traditional Industries: The Panel Threshold Methods and Applications. MA, Department of Economics, Feng Chia University.

Jensen, M. C. \& Ruback, R. S. (1983). The market for corporate control: the scientific evidence. Journal of Financial. Economics, 11, 5-50.

Jensen and Meckling, (1976). Theory of the firm: Managerial behavior, agency costs and ownership structure, Journal of Financial Economics, October, 3(4), 305-360.

Johnes, G. \& Johnes, J. (1993). Measuring the research performance of U.K. economics departments: An application of data envelopment analysis, Oxford Economic Paper, 45, 332-347.

Kimberly, J. R. \& Evanisko, M. J. (1981). Organizational innovation: The influence of individual, organizational, and contextual factors on hospital adoption of technological and administrative innovations, Academy of Management Journal, 24, 689-713.

Lai, Ju-Chien (1993). Financial management, Taipei: Hwatai Bookstore.

Lee, Yu-Je, Chao, Chia-Hui \& Chen, Ching-Yaw (2011). The Influence of interest in learning and learning hours on learning outcomes of vocational college students in Taiwan: using a teacher's instructional attitude as the moderator, Global Journal of Engineering Education, 13(3), 140-153.

Lee I-Chao, Yu-Je Lee, Yu-Je, Hui-Lin Chang, \& Lin Chin-Lang (20120). The influence of organizational change and culture on organizational effectiveness of senior nursing agencies in Taiwan: Using a moderator of investment for cloud computing technologies. American Journal of Business and Management, 1(1), 1-11.

Li, Fu-Li (2006). A Study of the relation between corporate governance and financial crisis: Taking the example of Publicly Traded Companies. MA, Department of Banking and Finance, Kainan University.

Li, Kun-Zhang (1998). A study of the correlations among company size, financial policies and performance in Taiwan: Taking the example of electronics companies. unpublished Master's thesis, Graduate Institute of Business Administration, Dayeh University.

Ling, Ya-Hui \& Hong, Ling (2010). How intellectual capital management affects organizational performance: Using intellectual capital as the mediating variable, Human Resource Management Student Newspaper, 10 (1), 1-17.

Liu, Cheng-Yi (2002). A study of how R\&D investments affects the financial policies and potential growth of a company: Taking the example of electronics and IT firms. MA, Department of Business Administration, Soochow University.

Lu, Ai-Zhi (2005). A study of how the internal and external corporate governance mechanisms are associated with financial performance. MA, Graduate Institute of Accounting, Tamkang University.

Modigliani, F. \& Miller, M. (1963). Corporate income taxes and the cost of capital, American Economic Review, 53, 433-443.

Peter F. Drucker (1966). The effective executive. Retrieved from www.gurteen.com/gurteen/gurteen.nsf/id/X0003C29A/ theopenforce.com

TEJ (Taiwan Economic Journal) (n.d). Retrieved from: http://image.tej.com.tw/lead

Wang, Jong-Chuen (1997). Performance management, Taipei: East West Management Consulting Inc.

Wu, Se-Hwa (1998). Knowledge flow and industrial innovations, Taiwan: the 7th Symposium on Industrial Management.

Xie, Xu-Zhong (2006). A study of the correlations among perceived organizational changes, organizational 
commitments and work performance: Taking the Example of Hsing Chung Paper Co. MA, Graduate Institute of Management, Fo Guang University.

$\mathrm{Xu}$, Nan-Xiong (2007). Organization theory and management, Taipei: Tsang Hai Book Publishing Company.

Yang, Xin-Zheng (1993). Examining the factors behind capital structure decisions of publicly traded companies.
Unpublished Master's thesis, Department of Business Administration, National Chung Hsin University.

Yermack, David (1996). Higher market valuation of companies with a small board of directors, Journal of Financial Economics, 40, 185-211.

Zahra, S. \& Pearce, J. (1989). Boards of directors and corporate financial performance: A review and integrative model, Journal of management, 15, 291. 